\title{
Melanoma cutáneo facial con gánglio centinela en región parotídea. Revisión de la literatura
}

\author{
Cutaneous melanoma of the face with sentinel node in parotid region. \\ Revision of the literature
}

\author{
R. del Rosario Regalado', Á. Rollón Mayordomo², C.I. Salazar Fernández², D. Moreno Ramírez², \\ T. Creo Martínez $z^{3}$ J.M. Pérez Sánchez ${ }^{4}$
}

Resumen: Introducción. La parótida es primer escalón ganglionar en la diseminación regional de los melanomas cutáneos de región frontal, orbitaria y nasal. Aunque la linfografía se ha convertido en una prueba diagnóstica estándar en el estudio del melanoma, no está exenta de inconvenientes.

Material y método. Presentamos el caso de un paciente con melanoma frontal y ganglios centinela parotídeos y discutimos las particularidades, ventajas y desventajas de la técnica en dicha región.

Conclusiones. Aunque se ha demostrado que la afectación del ganglio centinela es el factor predictor más importante de recurrencia y supervivencia, creemos que es una técnica en estudio cuyo efecto en la supervivencia debe ser demostrado frente a la alternativa de seguimiento clínico y que por tanto debe indicarse en casos seleccionados con mayor probabilidad de metástasis.

Palabras clave: Melanoma de cabeza y cuello; Linfografía; Disección cervical; Parotidectomía.

Recibido: 02.11 .05

Aceptado: 06.10.06
Abstract: Introduction. The parotid gland is the first lymph node echelon in the regional dissemination of frontal, orbital and nasal cutaneous melanomas. Although the lymphoscintigraphy has been become a standard diagnostic technique for studying melanomas, it is not exempt of inconveniences.

Material and methods. We present the case of a patient with frontal melanoma and sentinel nodes in the parotid region, and we discuss the peculiarities, advantages and disadvantages of using this technique in this region.

Conclusions. Although it has been proved that an affected sentinel lymph node is the most important prognostic factor for recurrence and survival, we believe that this is a technique under study, and that its influence on survival should be demonstrated with regard to the alternative of clinical monitoring. It should therefore be indicated in specific cases with greater probabilities of metastases.

Key words: Head and neck melanoma; Lymphoscintigraphy; Neck dissection; Parotidectomy.

\footnotetext{
1 Médico Residente.

2 Médico Adjunto.

3 Médico Residente.

4 Jefe de Servicio.

Servicio de Cirugía Oral y Maxilofacial

Hospital Universitario Virgen Macarena. Sevilla, España.
}

Correspondencia:

Ruth del Rosario Regalado

Avda/ Escultora La Roldana $\mathrm{n}^{\circ} 111^{\circ} \mathrm{A}$

41500 Alcalá de Guadaíra. Sevilla, España.

E-mail: ruthdelrosario@eresmas.com 


\section{Introducción}

La mayoría de melanomas cutáneos de cabeza y cuello se localizan en frente y cara. ${ }^{1,2}$

Las metástasis en ganglios linfáticos regionales se producen entre el 14 y $60 \%$ de los pacientes según estadios, ${ }^{3,4}$ y la región parotídea puede verse afectada en el $2,4 \%$ de los casos. ${ }^{5}$

La introducción de la linfoescintigrafia ha permitido localizar el probable primer escalón de drenaje ganglionar de la lesión, lo cual a su vez permite, mediante su extirpación, el diagnóstico precoz de la metástasis ganglionar con una cirugía relativamente simple, de poca morbilidad e incluso con anestesia local y a continuación, si se confirma la afectación, el tratamiento precoz mediante la linfadenectomía regional.6,7

A pesar de las ventajas que supone la técnica del ganglio centinela, existen opiniones contrarias sobre su utilidad e indicación generalizada, 8,9 siendo la región parotídea una de las zonas donde dichas controversias son mayores por sus características clínicas, técnicas y quirúrgicas. 5,10

Presentamos el caso de un paciente con melanoma frontal y ganglio centinela parotídeo, y discutimos las particularidades, ventajas e inconvenientes de la técnica en dicha región.

\section{Caso clínico}

Paciente de 24 años, sin antecedentes, que es intervenido por el servicio de Dermatología de nuestro hospital por presentar lesión melánica en región frontal. Dicha lesión es informada como melanoma maligno de extensión superficial con Breslow de $2 \mathrm{~mm}$ y estadio II.

En linfografía preoperatoria se objetivan dos ganglios centinela, uno primario en el seno de la glándula parótida izquierda y otro secundario en cola de dicha glándula. Tras este hallazgo se deriva a nuestro servicio para intervención, practicándose parotidectomía total conservadora y extirpación de tejido graso de polo inferior. El estudio anatomopatológico de la pieza quirúrgica descarta la presencia de metástasis.

La evolución del paciente es favorable y hasta el momento, tras 24 meses de seguimiento, no se han objetivado recidivas locales, ganglionares ni a distancia.

\section{Discusión}

La incidencia de metástasis en ganglios linfáticos parotídeos de melanomas cutáneos de región facial detectados mediante parotidectomía profiláctica es del 2,4\%,,$^{5}$ pudiendo llegar al $8 \%,{ }^{11}$ y $13 \%,{ }^{12}$ en estudios realizados con la técnica del ganglio centinela.

Debido a que la probabilidad de aparición de metástasis regionales en melanomas de cabeza y cuello es menor del $20 \%$ y que la linfadenectomía profiláctica no aumenta la supervivencia, ${ }^{13}$ la indicación de la disección ganglionar electiva es controvertida, optando muchos de los autores por realizar seguimiento del paciente y tratamiento de las metástasis en el momento de su detección. ${ }^{14}$

\section{Introduction}

Most cutaneous melanomas of the head and neck are located in the forehead and face $e^{1,2}$

Metastases to regional lymphatic nodes occurs in $14 \%$ to $60 \%$ of patients depending on stage, 3,4 and the parotid region can be affected in $2.4 \%$ of cases. ${ }^{5}$

The introduction of lymphoscintigraphy has permitted locating the first likely draining lymph node of the lesion. This in turn permits, following excision, the early diagnosis of nodal metastasis with relatively simple surgery, little morbidity and even under local anesthesia. If involvement is confirmed, early treatment by means of regional lymphadenectomy can be carried out.6,7

In spite of the advantages that the sentinel node technique represents, there are opinions against its general use and indication. 8,9 The parotid region is one of the areas where these controversies are greatest because of the clinical, technical and surgical characteristics of the region. 5,10

The case of a patient with melanoma of the frontal region and sentinel node in the parotid gland is presented and the peculiarities, advantages and disadvantages of using this technique in this area are discussed.

\section{Case report}

The patient was 24 years old male with no relevant medical history. He was operated by the department of Dermatology in our hospital as a result of a melanoma in the frontal region. The lesion was reported as stage II, superficial spreading malignant melanoma with a Breslow measurement of $2 \mathrm{~mm}$.

The preoperative lymphography showed two sentinel nodes, a primary one in the center of the left parotid gland, and another secondary one in the tail of the gland. After this finding he was referred to our service for surgical intervention, and a total conservative parotidectomy was carried out together with removal of fatty tissue from the lower axis. The anatomopathologic report of the surgical specimen ruled out the presence of metastasis.

The patient evolved favorably and to date, after a follow-up of 24 months, local, nodal or distant recurrence has not been observed.

\section{Discussion}

The incidence of metastasis in parotid lymph nodes of cutaneous melanoma of the facial region, detected by means of a prophylactic parotidectomy is $2.4 \%, 5$ and it can reach $8 \%{ }^{11}$ and $13 \%{ }^{12}$ in studies carried out with the sentinel node technique.

Given that the probability of regional metastasis from head and neck melanomas is lower than 20\%, and that pro- 
La disección cervical electiva o profiláctica supone el sobretratamiento o tratamiento no necesario de los pacientes sin metástasis ganglionares que oscilan entre el 95,7 y el $87 \%$ de los casos, 5,11,12 con lo que implica de aumento en la morbilidad y los costes.

En cabeza y cuello, dicho tratamiento electivo debería incluir en la mayoría de las ocasiones la región parotídea, mediante parotidectomía profiláctica, con los riesgos y secuelas que implica: debilidad temporal del nervio facial en el $15 \%$ y definitiva de alguna rama en menos del $5 \%, 15$ riesgo que se incrementa en la rama marginal si se asocia disección cervical electiva, síndrome de Frey en un $30 \%$ de los casos y secuelas estéticas por hundimiento o cicatriz. ${ }^{11,15}$

Otra cuestión discutida en el melanoma de cabeza y cuello se refiere a la predicción del camino de drenaje linfático regional para cada paciente. ${ }^{12,14}$ Mientras que para algunos autores las metástasis linfáticas cervicales siguen un modelo fijo y predecible, $14,16,17$ acertando en el $92,{ }^{18}$ y $97 \%,{ }^{19}$ de los pacientes, para otros, el modelo de distribución es variable. ${ }^{12,20}$ Sin embargo, dicha predicción solo identifica los niveles cervica-

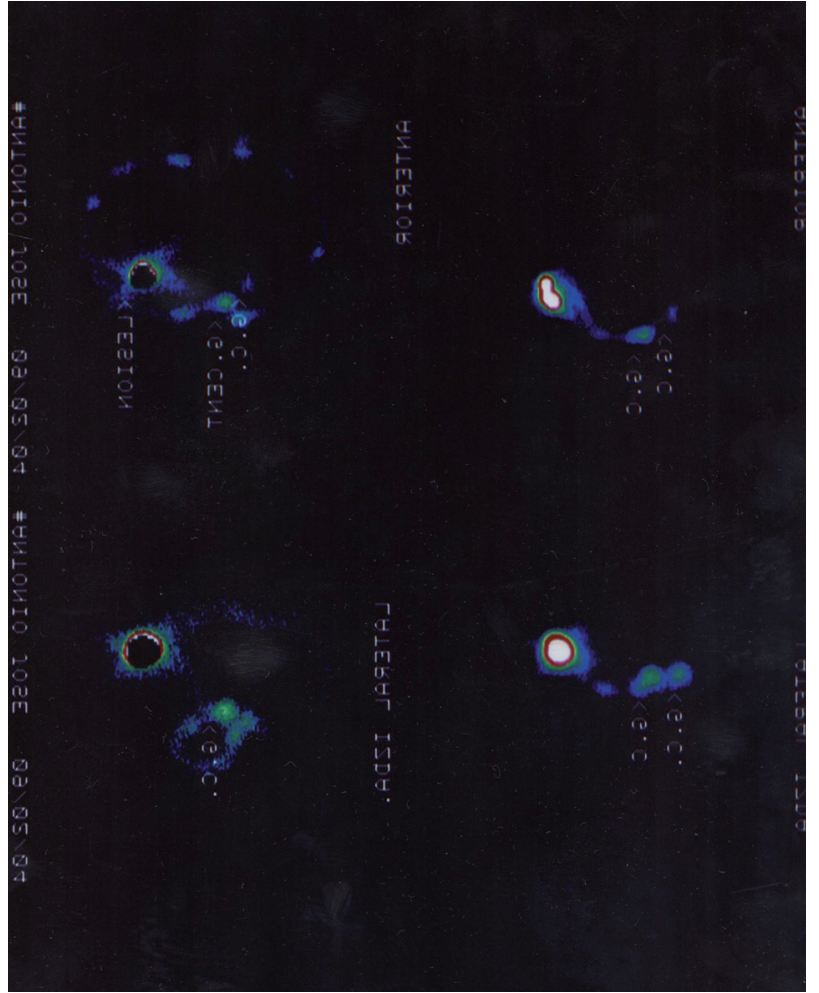

Figura 1. Linfografía preoperatoria donde se objetivan dos ganglios centinelas, uno primario en seno de glándula parótida izquierda y otro secundario en cola de dicha glándula.

Figure 1. Preoperative lymphography showing two sentinel nodes, one primary in the middle of the left parotid gland and the other secondary in the tail of the gland. les que pueden verse afectados por la diseminación, pero no el lugar exacto ni al paciente con metástasis. Nos permitiría por tanto realizar linfadenectomías regionales profilácticas más selectivas de los posibles niveles afectos, pero sin reducir su número, es decir, el número de pacientes que sobretratamos.

La ventaja que aporta la linfoescintigrafia es la localización del ganglio de drenaje de la lesión, el cual, tras su extirpación y análisis, confirmará aquellos pacientes con metástasis, permitiendo: $1^{\circ}$ conocer el patrón de drenaje linfático individual de cada paciente, $2^{\circ}$ el estadiaje exacto, $3^{\circ}$ la disección ganglionar terapéutica pre$\mathrm{coz}$ en un segundo tiempo, $4^{\circ}$ el tratamiento complementario adyuvante indicado y $5^{\circ}$ disponer de información pronóstica referente a supervivencia y recurrencia. Es una técnica quirúrgica diagnóstica indicada en melanomas cuya profundidad sea superior de $1 \mathrm{~mm}$ o con nivel de Clark IV. ${ }^{21,22}$ En los pacientes cuyo ganglio centinela sea negativo, la técnica evita la cirugía agresiva de la disección cervical electiva o la parotidectomía electiva y, por tanto, la morbilidad y coste. ${ }^{8}$

Sin embargo, la técnica del ganglio centinela también tiene inconvenientes y la información que aporta es controvertida, lo que hace que su justificación pueda ser dudosa frente a la pauta de esperar y ver evolución. ${ }^{9}$

En el 34\% de los pacientes la linfografía detecta ganglios que no concuerdan con los que la predicción clínica establece. ${ }^{10}$ Dicha discordancia consiste en la identificación como ganglios centinelas phylactic lymphadenectomies do not lead to increased survival, ${ }^{13}$ the indication for elective node dissection is controversial, and many authors opt for monitoring the patient and treating metastasis when detected. ${ }^{14}$

Elective or prophylactic neck dissection entails extra or unnecessary treatment for patients with no lymph node metastasis, which can vary between 95.7 and $87 \%$ of cases, $5,11,12$ and this implies increased morbidity and costs.

This elective treatment in the head and neck region should generally include the parotid region, and it should consist in a prophylactic parotidectomy, with the risks and sequelae that this implies: temporary facial nerve weakness in $15 \%$ of patients and permanent branch weakness in under $5 \%, 15$ a risk that increases in the marginal branch if accompanied by elective neck dissection, or Frey's syndrome to 30\% together with the aesthetic sequelae due to indentation or scarring. 11,15

Another disputed aspect of head and neck melanoma concerns predicting each patient's regional lymphatic drainage path. ${ }^{12,14}$ While some authors believe that lymphatic metastases to the neck follow a fixed and predictable model, $14,16,17$ which in $92 \% 18$ and $97 \%{ }^{19}$ of patients is identified correctly, for others the distribution pattern is variable. ${ }^{12,20}$ However, this prediction only identifies the neck areas that can be affected by dissemination, but not the exact site or the patient with metastasis. This allows more selective prophylactic regional lymphadenectomies to be carried out of the areas that are possibly affected, but without a reduction in number, that is, the number of patients that are overtreated.

The advantage of the lymphoscintigraphy is that the lesion's drainage node can be located and, after removal and analysis, those patients with metastases can be identified. This will permit the following: Firstly, knowing the individual lymphatic drainage pattern of each patient. Secondly, the exact stage. Thirdly, it will permit early therapeutic node dissection in a second procedure. Fourthly, the adjuvant complementary therapy indicated can be carried out. And fifthly, it will allow having prognostic information with 
de los ganglios retroauriculares en el $13,4 \%$ y contralaterales en el $72 \%$, hallazgos contrarios a los observados durante el seguimiento, donde los casos de metástasis en dichos ganglios oscilan entre 1,5-2,9\%.10,18,19

La técnica presenta una tasa de falsos negativos menor del $4 \%$ si lo determinamos mediante la disección ganglionar realizada concomitantemente. ${ }^{23}$ Sin embargo, si el criterio es la recurrencia en la zona del ganglio centinela sin disección previa, la tasa de falsos negativos puede variar entre el 0 y el $25 \%$ en función del tiempo de seguimiento, el estudio anátomo-patológico realizado (inmunohistoquímico o no), la experiencia del equipo investigador y el método utilizado.9,10,12 Creemos que algunos resultados pueden mejorarse con la utilización de gamma probe (sonda intraoperatoria) como emplean Lin y cols. ${ }^{24}$

Las complicaciones descritas son bajas e incluyen: seroma (3\%), infección de la herida (3\%), hematoma $(2,5 \%)$, reacción alérgica, ${ }^{24,25}$ y se discute el riesgo de si la inyección de radiofármaco y colorante puede aumentar las metástasis en tránsito. ${ }^{24,26}$

Finalmente, estamos ante una intervención solo diagnóstica donde no existen datos sobre la eficacia en relación a la supervivencia, es decir, si el tratamiento precoz de estos pacientes una vez se detecte la metástasis mejora su supervivencia. ${ }^{9}$

Las consideraciones que hay que tener presente ante un ganglio centinela en región parotídea son las generales descritas anteriormente a las que hay que añadir las determinadas por su localización, cuya proximidad al nervio facial hace que su extirpación sea más complicada. ${ }^{10,12}$

La incidencia de metástasis linfáticas parotídeas en melanoma de cabeza y cuello en estadios iniciales se mantiene entre un 2,4\%$13 \%, 5,11,12$ sin embargo la detección de ganglios centinelas preoperatorios en dicha región varia entre el 95 y 35,2\%,10-12 lo que se puede explicar por diferencias de aparatología y experiencia del equipo.

Según la localización, los ganglios centinelas de la región parotídea se pueden clasificar en intraparotídeos, que asientan en el interior de la glándula, y periparotideos, que asientan por fuera o en la perifería (estos a su vez se clasifican en anteriores, infraglandulares y supraglandulares). ${ }^{11,12}$ En las series de Olilla y cols. ${ }^{12}$ y Fincher y cols. ${ }^{11}$ la distribución de ganglios intraparotídeos y extraparotídeos es al 50\%.

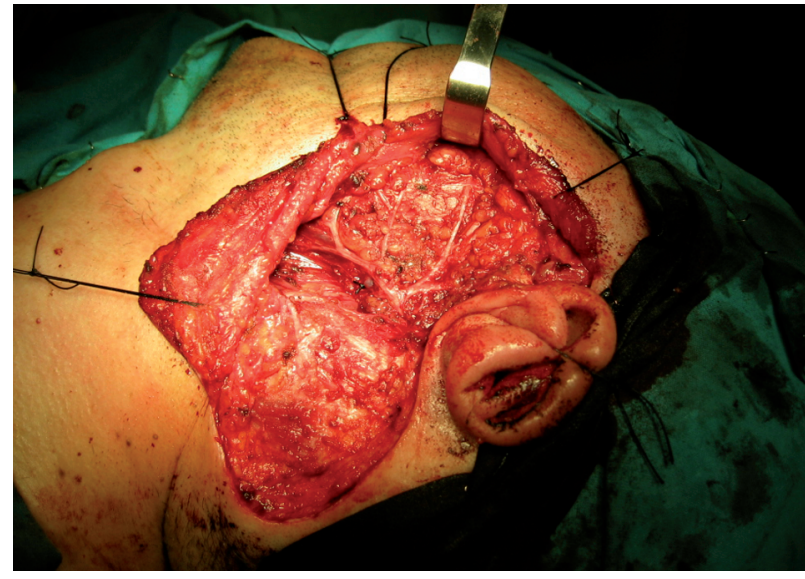

Figura 2. Imágen intraoparatoria tras disección de lóbulo superficial parotídeo.

Figure 2. Intraoperative view after dissection of the superficial lobe of the parotid gland.

parotídeo.

Figure 3. Intraoperative view after dissection of deep lobe of the parotid gland regard to survival and recurrence. This is a surgical diagnostic technique that is indicated for melanomas with a depth of over $1 \mathrm{~mm}$ or Clark level IV.21,22 For those patients with a negative sentinel node, the technique avoids aggressive surgery such as elective neck dissection or an elective parotidectomy and therefore, the morbidity and cost. ${ }^{8}$

However, the sentinel node technique also has disadvantages and the information that it provides is controversial, which means that justifying its use, as opposed to waiting and watching, can be difficult. ${ }^{9}$

In $34 \%$ of patients the lymphography detects nodes that do not correspond with those predicted clinically. ${ }^{10}$ This discordance consists in identifying as sentinel nodes retroauricular nodes in $13.4 \%$ of cases, and contralateral nodes in $72 \%$ of cases. These are findings that are contrary to those observed during monitoring, as the incidence of metastases in these nodes varies between 1.5-2.9\%.10,18,19

The technique has a rate of false negatives that is less than $4 \%$ if concomitant node dissection is carried out. ${ }^{23}$ However, if the criteria is recurrence in the region of the sentinel node with no previous dissection, the rate of false negatives can vary between 0 and $25 \%$ depending on the follow-up period, the anatomopathological study carried out (immunohistochemical or not), the experience of the investigating team and the method used.9,10,12 We believe that some results can be improved by using an intraoperative gamma probe as used by Lin et al. ${ }^{24}$

Few complications have been described and they include: seroma (3\%), infection of the wound (3\%), hematoma (2.5\%), allergic reaction. ${ }^{24,25}$ There is also some discussion as to radioactive tracers and coloring materials contributing to increased in-transit metastasis. ${ }^{24,26}$

Finally, it should be kept in mind that this is an intervention that is purely diagnostic, and there are no data as 
Aunque algunos autores cuestionan la seguridad de realizar la linfadenectomía del ganglio centinela en la región parotídea, ${ }^{5,10}$ Olilla y cols. ${ }^{12}$ la realizan en 37 de sus 39 pacientes y Fincher $y$ cols. ${ }^{11}$ en 12 de sus 18 pacientes ( 6 con ganglios periparotídeos y 3 intraparotídeos), considerando que los intraparotídeos se pueden extirpar con mínimo riesgo ${ }^{11}$ y aconsejando una disección meticulosa intraglandular y el uso prudente de electrobisturí. 11,12

Ante el riesgo de una lesión definitiva del nervio facial, la alternativa es la de realizar una parotidectomía conservadora, ${ }^{27}$ previa localización y disección del nervio facial, extirpando la glándula donde se encuentre el ganglio, lo que realizan Fincher y cols. ${ }^{11}$ en los 6 pacientes restantes (33\% del total) con ganglios intraparotídeos. Esto supone realizar una parotidectomía profiláctica, cirugía de mayor envergadura cuyo tiempo de quirófano y estancia hospitalaria es superior a una simple adenectomía.

El principal inconveniente de la adenectomía aislada es la lesión del nervio durante la extirpación, o en un segundo tiempo si fuese necesario la parotidectomía. Para evitarlo, Lin y cols, ${ }^{24}$ recomiendan la utilización de sistemas de monitorización intraoperatorios no invasivos. Olilla y cols. ${ }^{12}$ presentan como única complicación en su serie de 37 linfadenectomías parotídeas un caso (2,6\% de los pacientes) de paresia del nervio facial transitoria, incluso extirpando una media de 2-3 ganglios por paciente, Fincher, ${ }^{11}$ en su serie de 12 linfadenectomías en parótida, no presenta ninguna complicación al igual que Lin. ${ }^{24}$

En parótida, la tasa de falsos negativos es del 3,1\%-12,5\%. 10,12,23 La sensibilidad de la técnica es del $64-80 \%$, es decir, de los pacientes que tienen metástasis subclínicas en parótida, un 20-36\% no son detectados (falsos negativos), ${ }^{10,12,24}$ lo cual se puede explicar por el pequeño tamaño de los ganglios. ${ }^{10,11}$

Con el fin de mejorar estos resultados se aconseja evitar la inyección abundante de contraste en los melanomas de mejilla, para impedir su extravasación o superposición con la parótida, y levantar colgajos de piel finos, para evitar incluir los ganglios en el colgajo. ${ }^{14}$

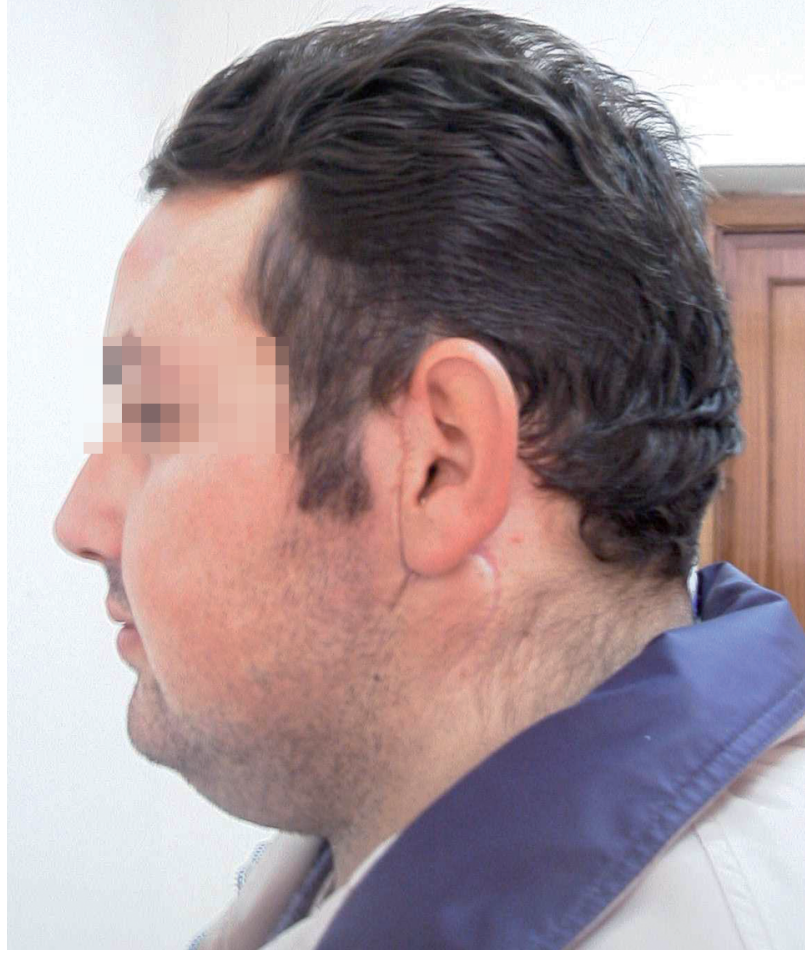

Figura 4. Imágen postoperatoria a los 11 meses de seguimiento. Figure 4. Postoperative view after a follow-up of 11 months.

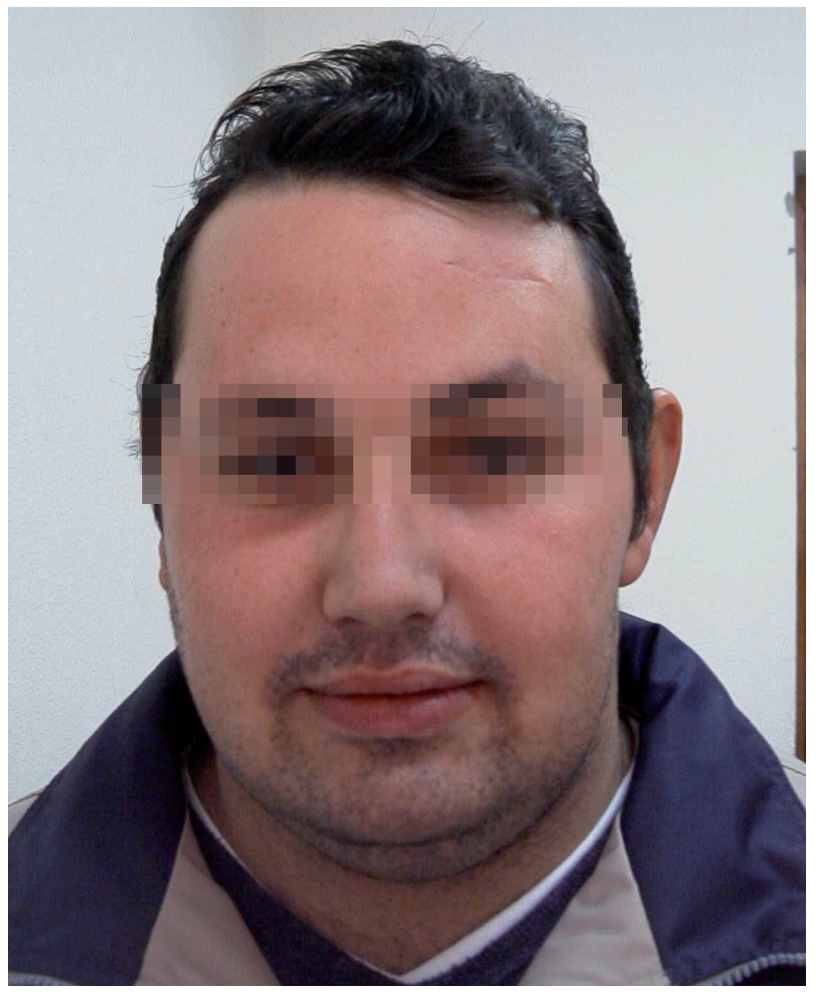

Figura 5. Imágen postoperatoria a los 11 meses de seguimiento. Figure 5. Postoperative view after a follow-up of 11 months. to its efficiency with regard to survival - that is to say, if prompt treatment of these patients, once metastasis has been detected, improves survival. ${ }^{9}$

The aspects that have to be taken into account with a sentinel node in the parotid region are the general aspects that have previously been described, and to which we have to add those related to location, as if the sentinel node is close to the facial nerve, excision is more complicated. ${ }^{10,12}$

The incidence of lymphatic metastasis of the parotid region in early stage melanomas of the head and neck is around 2.4\%$13 \%, 5,11,12$ however the detection of preoperative sentinel nodes in this region varies between $95 \%$ and $35.2 \%,{ }^{10-12}$ which can be explained by differences in equipment and in the experience of the team.

Sentinel nodes of the parotid region can be classified as intraparotid, those that are situated within the gland, or periparotid, which are situated on the outside or in the peripheral area (these in turn are classified as anterior, infraglandular and supraglandular). ${ }^{11,12}$ In the series by Ollila et al. ${ }^{12}$ and Fincher et al. ${ }^{11}$ the distribution between intraparotid and extraparotid nodes was $50 \%$.

Although some authors question the safety of carrying out a lymphadenectomy of the sentinel node in the parotid region, 5,10 Ollila et al. ${ }^{12}$ carried this out in 37 out of their 39 patients, and Fincher et al. ${ }^{11}$ in 12 out of their 18 patients (6 with periparotid nodes and 3 with intraparotid nodes), as they considered that intraparotid nodes 
Una vez confirmada la afectación del ganglio parotídeo, la mayoría de autores están de acuerdo en realizar parotidectomía total conservandora y algunos también asocian la disección cervical 12,14 ya que el $50 \%$ de los pacientes con ganglio parotídeo afectado presentan o presentarán metástasis cervicales. ${ }^{12}$

La mayoría de los ganglios parotídeos se localizan en la región superficial de la glándula.5,26 Según estudios anatómicos, en el lóbulo superficial pueden asentar hasta 20 ganglios y en el profundo entre 0-5 ganglios. ${ }^{28,29}$ Aunque pudiera parecer que la parotidectomía superficial no supone un tratamiento electivo eficaz por no eliminar la totalidad de ganglios intraglandulares, si se realiza sin objetivar ganglios positivos, no se describen recidivas posteriores en lóbulo profundo. ${ }^{5}$ Sin embargo no está claro si tras una parotidectomía superficial con ganglios positivos es preciso realizar posteriormente una parotidectomía profunda, sobre todo en los casos donde la parotidectomía se haya realizado como técnica de extirpación del ganglio centinela.

\section{Conclusión}

Aunque se ha demostrado que la afectación del ganglio centinela es el factor más importante predictor de recurrencia y supervivencia, ${ }^{23}$ tenemos la duda de que esta habilidad justifique el que realicemos una prueba diagnóstica-quirúrgica, sin esperar a que esté demostrada su eficacia en la supervivencia frente a la alternativa de seguimiento clínico.

Creemos que debe indicarse selectivamente e individualmente, como técnica experimental o dentro de ensayos clínicos, ${ }^{9}$ como realizamos en nuestro hospital.

En los casos que se realicen y se detecten ganglios en la región parotídea deberemos analizar la linfografia preoperatoria para distinguir si el/los ganglios son periparotídeos o intraparotídeos y en estos últimos, valorar el grado de profundidad.

En ganglios periparotídeos e intraparotídeos superficiales realizaremos ecografía previa de alta resolución, que permitirá confirmar la existencia y localización de adenopatías de hasta $2,5 \mathrm{~mm}$, que serán confirmadas intraoperatoriamente con la sonda, y adenectomía.

En ganglios intraparotídeos profundos, ante el riesgo de lesión nerviosa, creemos que lo indicado es la parotidectomía superficial conservadora, confirmando tras su extirpación con la sonda, que se han extirpado todos los ganglios, sin dejar restos en el lóbulo profundo o nivel I cervical.

\section{Bibliografía}

1. O'Brien CJ, Coates AS, Petersen-Schaefer K, Shannon K, Thompson SF, Milton $\mathrm{GW}$, et al. Experience with 998 cutaneous melanomas of the head and neck over 30 years. Am / Surg 1991;162: 310-4.

2. Kane WJ, Yugueros P, Clay RP, Woods JE. Treatment outcome for 424 primary cases of clinical stage I cutaneous malignant melanoma of head and neck. Head Neck 1997; 19:457-65.

3. Myers JN. Value of neck disection in the treatment of patients wiyh intermediate-thickness cutaneous malignant melanoma of the head and neck. Arch Otolaryngol Head Neck Surg 1999;125:110-5. could be excised with minimal risk. ${ }^{11}$ They recommend meticulous intraglandular dissection, and that the electric bistoury be used prudently. ${ }^{11,12}$

Given the risk of permanent damage to the facial nerve, the alternative is carrying out a conservative parotidecto$m y^{27}$ before locating and dissecting the facial nerve, and removing the gland where the node is located, as carried out by Fincher et al. ${ }^{11}$ in their six remaining patients (33\% in total) with intraparotid nodes. This entails carrying out a prophylactic parotidectomy, and the surgery will be more extensive. In addition surgical time and hospital stay will be greater than with a simple adenectomy.

The main inconvenience of an isolated adenectomy is damaging the nerve on excision, or a second surgical procedure if a parotidectomy were necessary. In order to avoid this, Lin et a ${ }^{24}$ recommend the use of systems for non-invasive intraoperative monitoring. The only complication for Ollila et al. 12 in their series of 37 lymphadenectomies of the parotid region, was one case (2.6\% of patients) of transitory paresis of the facial nerve, even when an average of 2.3 nodes per patient were excised. Fincher et al, ${ }^{11}$ in their series of 12 lymphadenectomies of the parotid region, did not encounter any complications, nor did Lin. ${ }^{24}$

In the parotid, the rate of false negatives was 3.1\%$12.5 \% .10,12,23$ The sensitivity of the technique was $64-80 \%$. In other words, of the patients that had subclinical metastasis in the parotid, 20-36\% were not detected (false negatives), 10,12,24 which can be explained by the small size of the nodes. 10,11

With the aim of improving results, injecting abundant contrast material should be avoided for melanomas of the cheek, so as to avoid extravasation or the superpositioning of the parotid, and raising fine skin flaps, so as to avoid including any nodes in the flap has also been recommended. ${ }^{14}$

Once involvement of the parotid gland has been confirmed, most authors agree that a total conservative parotidectomy should be carried out, and some are in favor of also carrying out neck dissection ${ }^{12,14}$ as 50\% of patients with affected parotid nodes have, or will have, neck metastasis. ${ }^{12}$

Most parotid nodes are located in the superficial region of the gland. ${ }^{5,26}$ According to anatomic studies, in the superficial lobe there may be up to 20 nodes and in the deep lobe there may be 0-5 lobes. ${ }^{28,29}$ Although it would appear that the superficial parotidectomy is not effective elective treatment, as not all intraglandular nodes are eliminated, if this is carried out and no positive nodes are observed, it should be kept in mind that recurrence in the deep lobe has not been described. ${ }^{5}$ However, it is not clear if, after a superficial parotidectomy with positive nodes, a deep parotidectomy will have to be carried out later, especially in those cases where a parotidectomy has been carried out as a technique for removing a sentinel node. 
4. Harris C, Bailey J, Blanchaert RH. Surgical management of cutaneous melanoma of the head and neck. Oral Maxillofacial Surg Clin North Am 2005;17:191204.

5. O’Brien CJ, Petersen-Schaefer K, Papadopoulos T, Malka V. Evaluation of 107 therapeutic and elective parotidectomies for cutaneous melanoma. Am / Surg 1994;168:400-3.

6. Morton DL, Wen DR, Wong JM, Economou JS, Cagle LA, Storm FK, y cols. Technical details of intraoperative lymphatic mapping for early stage melanoma. Arch surg 1992;127:392-9.

7. Morton DL, Wen DR, Foshag LJ, Essner R, Cochran A. Intraoperative lymphatic mapping and selective cervical lymphadenectomy for early-stage melanomas of the head and neck. / Clin Oncol 1993;11:1751-6.

8. Brobeil A, Cruse CW, Messina JL, Glass LF, Haddad FF, Berman CG, y cols. Cost analysis of sentinel lymph node biopsy as an alternative to elective lymph node dissection in patients with malignant melanoma. Surg Oncol Clin North Am 1999; 8:435-45.

9. Meirion Thomas J, Patocskai EJ. The argument against sentinel node biopsy for malignant melanoma. BMJ 2000;321:3-4.

10. O’Brien CJ, Uren RF, Thompson JF, Howman-Giles RB, Petersen-Schaefer K, Shaw $\mathrm{HN}, \mathrm{y}$ cols. Prediction of potential metastatic sites in cutaneous head and neck melanoma using lymphoscintigraphy. Am / Surg 1995;170:461-6.

11. Fincher TR, O`Brien JC, McCarty TM, Fisher TL, Preskitt JT, Lieberman ZH, y cols. Patters of drainage and recurrence following sentinel lymph node biopsy for cutaneous melanoma of the head and neck. Arch Otolaryngol Head Neck Surg $2004 ; 130: 844-848$.

12. Ollila DW, Foshag LJ, Essner R, Stern SL, Morton DL. Parotid region lymphatic mapping and sentinel lymphadenectomy for cutaneous melanoma. Annals of Surgical Oncology 1999;6:150-4.

13. Lens MB, Dawes $M$, Goodacre $T$, Newton-Bishop JA. Elective lymph node dissection in patients with melanoma. Arch surg 2002;137:458-61.

14. O’Brien CJ, Shah JP, Balm AJ. Neck dissection and parotidectomy for melanoma. En: Textbook of Melanoma. Ed Thompson JF, Morton DL, Kroon BB. London Libro 2004;296-306.

15. Bron LP, O`Brien C]. Facial nerve function after parotidectomy. Arch Otolaryngol Head Neck Surg 1997;123:1091-6.

16. Wells KE, Cruce CW, Daniels S, Berman C, Norman J, Reintgen DS. The use of lymphoscintigrafy in melanoma of the head and neck. Plast Reconstr Surg 1994; 93:757-61.

17. Shah JP, Kraus DH, Dubner S, Sarkar S. Patters of regional lymphatic metastases from cutaneous melanomas of the head and neck. Am / Surg 1991;162:3203.

18. Pathak I, O`Brien CJ, Petersen-Schaeffer K, McNeil EB, McMahon J, Quinn MJ, y cols. Do nodal metastases from cutaneous melanoma of the head and neck follow a clinically predictable pattern? Head Neck 2001;23:785-790.

19. O'Brien CJ, Petersen-Schaefer K, Ruark D, Coates AS, Menzie SJ, Harrison RI, y cols. Radical, modified and selective neck dissection for cutaneous malignant melanoma. Head Neck 1995;17:232-41.

20. Norman J, Cruse CW, Espinosa C, Cox C, Berman C, Clark R, y cols. Redefinition of lymphatic drainage with the use of lymphoscintigraphy for cutaneous melanoma. Am / Surg 1991;162:432-7.

21. Balch CM, Mihm MC. Reply to the article "The AJCC staging proposal for cutaneous melanoma: comments by the EORTC Melanoma Group" by DJ Ruiter y cols. (Ann Oncol 2001;12:9-11). Ann Oncol 2002;13:175-6.

22. Morris KT, Stevens JS, Pommier RF, Fletcher WS, Vetto JT. Usefulness of preoperative lymphoscintigraphy for the identification of sentinel lymph nodes in melanoma. Am / surg 2001;181:423-6.

\section{Conclusion}

Although it has been demonstrated that an affected sentinel node is the most important factor for predicting recurrence and survival, ${ }^{23}$ we have some doubts as to whether this factor justifies carrying out diagnostic-surgical tests, as opposed to the alternative which would be clinical following. We should perhaps wait for its efficacy with regard to survival to be demonstrated. We believe that it should be indicated selectively and individually as an experimental technique, or used within clinical trials9 as occurs in our hospital.

In cases where this is carried out, and where nodes are detected in the parotid region, the preoperative lymphography should be analyzed in order to distinguish if the node or nodes are periparotid or intraparotid, and in this last case the depth involved should be evaluated.

For superficial periparotid and intraparotid nodes, highresolution ultrasound should be carried out, which will permit confirming the existence and location of adenopathies that measure up to $2.5 \mathrm{~mm}$, and that are confirmed intraoperatively by probe, and adenectomy.

In deep intraparotid nodes, when there is risk of nerve damage, we believe that what should be indicated is a superficial conservative parotidectomy. Confirmation should then be carried out by probe that all nodes have been removed, and that no remains have been left in the deep lobe or level I of the neck. 
23. Gershenwald JE, Thompson W, Mansfield PF, Lee JE, Colome MI, Tseng $C$, et al. Multi-institutional melanoma lymphatic mapping experience: the prognostic value of sentinel lymph node status in 612 stage I o II melanoma patients. / Clin Oncol 1999;17:976-83.

24. Lin D, Kashani-Sabet M, Singer MI. Role of the head and neck surgeon in sentinel lymph node biopsy for cutaneous head and neck melanoma. Laryngoscope 2005;115:213-7.

25. Jansen L, Nieweg OE, Peterse JL, Hoefnagel CA, Olmos RA, Kroon BBR. Reliability of sentinel lymph node biopsy for staging melanoma. $\mathrm{Br}$ J Surg 2000;87: 484-9.

26. Muller MGS, Van Leeuwen PAM, Pijpers R, Van Diest PJ, Meijer S. Pattern and incidence of first site recurrence following sentinel node procedure in melanoma patients. Eur J Surg Oncol 2000;26: 272.

27. Eicher SA, Clayman G, Myers J, Gillenwater A. A prospective study of intraoperative lymphatic mapping for head and neck cutaneous melanoma. Arch Otolaryngol Head Neck Surg 2002;128:2416.

28. Barr LC, Skene Al, Fish S, Thomas JM. Superficial parotidectomy in the treatment of cutaneous melanoma of the head and neck. Br / Surg 1994; 81:64-5.

29. McKean ME, Lee K, McGregor IA. The distribution of lymph nodes in and around the parotid gland: an anatomical study. Br J Plast Surg 1985;38:1-5. 